University of Thi-Qar Journal Vol.10 No.3 SEP 2015

Web Site: https://jutq.utq.edu.iq/index.php/main Email: journal@jutq.utq.edu.iq

\title{
Toll-Like Receptor 4 Gene Polymorphisms in patients withUrinary Tract Infection https://doi.org/10.32792/utq/utj/vol10/3/7
}

\author{
Dr. Hammadi A. Al-Hilaly ${ }^{1}$, Dr. AliN. Salman ${ }^{2}$ and Ahmed H. Dakheel ${ }^{3}$ \\ ${ }^{1}$ Department of Medical Microbiology, College of Medicine, Al-Qadisiya \\ University, Diwaniya, Iraq, \\ Email:hamadyalhilaly@yaoo.com. \\ ${ }^{2}$ College of Nursing, Thi-qar University, Nasiriya, Iraq, \\ Email: ali69na@Gmail.com. \\ ${ }^{3}$ Department of Medical Microbiology, College of Medicine, Al-Qadisiya \\ University, Diwaniya, Iraq, \\ Email:ahmedhadi707@yahoo.com.
}

\begin{abstract}
Background: Urinary tract infection (UTIs) are considered to be the most common infections in humans.

Aims:The present study aimed to investigate the association between single nucleotide polymorphisms (SNPs) in the toll-like receptor 4 (Tlr4) gene (Thr399Ile) and the incidence of Urinary Tract Infection.

Subjects and Methods: A total of 49 patients with Urinary Tract Infection and 25 apparently healthy control were enrolled in this study. Urine samples from patients with UTI was collected in AL-Imam AL-Hussain teaching hospital in Thi- Qar province, during the period from February 2014 to March 2015.. Urinary isolates were identified by conventional methods.DNA was extracted from the blood samples taken from these participants. TLR4 gene was amplified with polymerase chain reaction (PCR) using specific primers. Genotyping of the SNPs of interest was done by restriction fragment length polymorphism (RFLP).

Results:The present study was showed 26 (53.06\%)isolates Escherichia coli; 9 (18.37\%) isolates had Pseudomonas aeruginusa;7 (14.29\%) isolates had Klebsiella pneumonia; 4 (8.16\%) had Proteus and $3(6.12 \%)$ isolates had Klebsiellaoxytoca, the results showed the presence of heterozygous in one sample from study group at site 399 (C / T) after using restriction enzyme Hinfl.

Conclusion: Escherichia coli was most common causative agent in UTI, Thr399Ile may be considered as a risk factor that increases susceptibility to Urinary TractInfection.
\end{abstract}

Key words: Urinary Tract Infection, toll-like receptor 4, single nucleotide polymorphism 


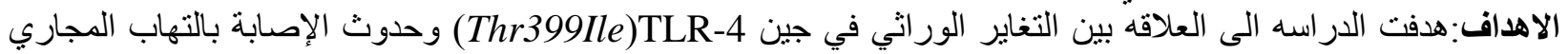

الاشخاص وطرق العمل: شملت الدراسة 49 شخصا يعاني من التهاب المجاري البولية وكذلك 25 شخص شئ من الإنساء

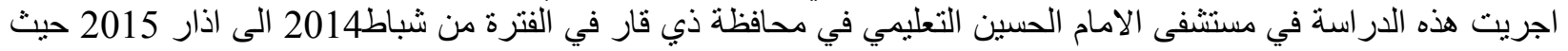
جمعت عينات البول وشخصت البكتيريا بالطرق المختبرية ـ عينات الدم جمعت اذ تم استخلاص الحامض النين النوويو استعملت تقنية

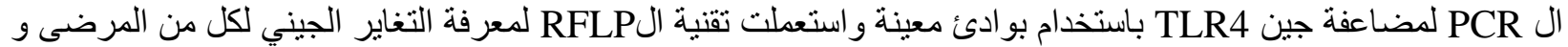

7 النتائج:اظهرت , proteus (\%8.16) 4 ,klebsiellapneumonia(\%14.29),Pseudomonasaeruginusa الظهرت النتائج وجود طفره واحده غير متجانسه لأحد المرضى المصابين بالتهاب المجاري

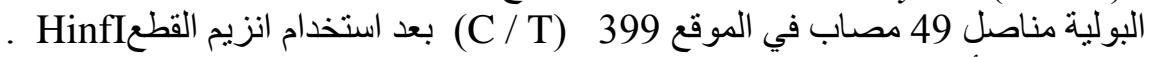

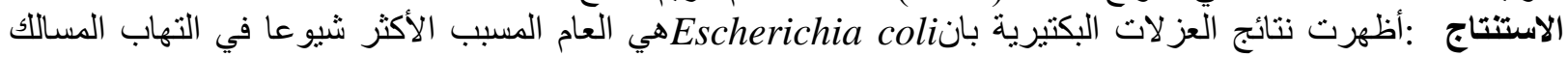

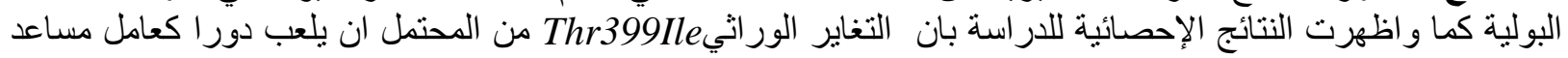
للاصابة بالتهاب المجاري البوليه.

\section{Introduction}

Urinary tract infections (UTIs) are considered to be most common infections in humans (Bien et al.,2012). UTIs are classified into disease categories according to the site of injury: cystitis (the bladder), pyelonephritis (the kidney) and bacteriuria (the urine) (Foxman, 2003). Colonization of the urine in absence of the clinical symptoms is called asymptomatic bacteriuria (ABU) (Bien et al.,2012). Most patients with ABU do not need treatment, and in many cases the colonizing by the $\mathrm{ABU}$ strains may help to prevent infection by other more virulent bacteria (Hull et al.,2000;Darouicheet al.,2001;Trautner et al.,2003).

In most of the cases UTIs are caused by Gramnegative bacteria from the intestinal flora (Köves, 2014). The primary causative agents responsible for more than $80 \%$ of all UTIs including both $\mathrm{ABU}$ and symptomatic UTIs, are strains of uropathogenicE. coli (Sadler et al.,1989; Hooton and Stamm,1997; Svanborg and Godaly,1997).

Toll-like receptors (TLRs) are transmembranous signaling receptors which play a key role in the innate and adaptive immune response, since they are involved in the regulation of inflammatory response and activation of the adaptive immune cellsto reduce infectious pathogens and cancer cells (Iwasaki and Medzhitov,2010). To date, ten different types of TLRs 


\section{University of Thi-Qar Journal Vol.10 No.3 SEP 2015}

Web Site: https://jutq.utq.edu.iq/index.php/main Email: journal@jutq.utq.edu.iq

have been described in human which are capable of specifically recognized different pathogens and/or endogenous damage molecules (Iwasaki and Medzhitov, 2004). TLR4 is one of the most prominent members of TLRs which is present in immune and non- immune cells.

The activation of the innate immune response in the urinary tract is dependent on recognition of bacterial components, products by TLRs (Hedlundet al., 2001;Andersen-Nissenet al., 2007). In recent years, it has become clear that the immune activation of bladder and kidney epithelial cells depends on TLRs, including TLR4, TLR5, and TLR11 (Samuelsson et al.,2004; Song and Abraham, 2008).

TLR4 gene is highly polymorphic, and to date, 15 polymorphisms in its coding sequence have been identified (Schroder and Schumann, 2005). Two common cosegregated single nucleotide polymorphisms (SNP) on the human TLR4 gene were reported. One SNP is an Adenin (A) to Guanin (G) substitution at nucleotid position 896 from the start codon of the TLR4 cDNA. The single nucleotide exchange results in replacement of a conserved aspartic acid residue with glycine at amino acid position 299 (Asp299Gly) (dbSNP databank: rs4986790), The second missense polymorphism results in a change of cytosin (C) to thymin (T) at nucleotid position 1196 from the start codon (dbSNP databank: rs4986791), which causes replacement of a nonconserved threonine with an isoleucine at amino acid position 399 (Thr399Ile) in the extracellular domain of the TLR4 receptor. The average incidence of these polymorphisms is about 10\% in the Caucasian population (Reismann, 2009).

The present study was aimed to investigate the association of Thr399Ile SNPs in Tlr4 gene with incidence of UTI in Iraqi patients.

\section{Subjects and Methods}

The study population consisted of 49 (2-75 years old, mean 39.96+16.88, 17 males and 32 females) in patients with Urinary Tract Infection and there urine culture showed positive result of Gram negative bacteria., and 25 age matched (10 males and 15 females) healthy controls. All participants were recruited from AL-Imam AL-Hussain teaching hospital in Thi- Qar province, during the period from February 2014 to March 2015. 


\section{University of Thi-Qar Journal Vol.10 No.3 SEP 2015}

Web Site: https://jutq.utq.edu.iq/index.php/main Email: journal@jutq.utq.edu.iq

Urine samples were taken by standard mid-stream "clean catch" method from patients and Five milliliters of venous blood was taken in EDTA tubes which kept at -20 until be used for DNA extraction.The urine samples were cultured on plates of Blood agar and MacConkey agar media and the sample plates were incubated at $37^{\circ} \mathrm{C}$ for overnight. The cultures were subjected to identification of the organisms by using microscopical and macroscopical examinations and routine biochemical tests (Vandepitteet al., 2003).

\section{DNA extraction and genotyping of $T L R 4$ gene}

DNA was extracted from the blood samples by using manual method(Sambrooket al., 1989). The primer used for amplification of TLR4 gene (Bioneer/Korea) are shown in table 1.

Template DNA $(3 \mu \mathrm{L})$ from each sample, $(1 \mu \mathrm{L})$ from each primers were added and $(10 \mu \mathrm{L})$ of Deionized sterile $\mathrm{H} 2 \mathrm{O}$ wasadded to each master-mix tube $(50 \mu \mathrm{L}$ PCR master-mix, Bioneer/Korea). The mixture then put in shaker. After mixing, the master-mix tubes were transferred to the thermo cycler (BioRad/Singapore) which is previously programmed with certain protocol according to gene to be amplified.cycling conditions were an initial denaturation for $5 \mathrm{~min}$ at $95^{\circ} \mathrm{C}$, followed by 35 cycles of denaturation at $95^{\circ} \mathrm{C}$ for $40 \mathrm{sec}$, annealing at $60{ }^{\circ} \mathrm{C}$ for $40 \mathrm{sec}$, extension at $72{ }^{\circ} \mathrm{C}$ for $50 \mathrm{sec}$, followed by final extension at $72{ }^{\circ} \mathrm{C}$ for $5 \mathrm{~min}$.

For digestion $(10 \mu \mathrm{L})$ from Thr399Ile PCR products was mixed with a $1 \mu \mathrm{L} 10 \mathrm{X}$ buffer $\mathrm{R}$ and $1 \mu \mathrm{LHinfl}(10 \mathrm{U})$ restriction enzyme. Deionized sterile $\mathrm{H} 2 \mathrm{O}$ was used to adjust the volume to $30 \mu \mathrm{L}$. The mixture was then incubated $37 \mathrm{C}$ at overnight.

\section{Agrose gel electrophoresis}

A $2 \%$ gel was prepared, and $10 \mu \mathrm{L}$ aliquot of digestedPCR product from each sample was loaded into the wells. After 1 hour of electrophoresis, the gel was previously prepared, stained with ethidium bromide (Biobasic/Canada) $(0.5 \mu \mathrm{L} / \mathrm{mL})$. The amplified products were determined by comparison with a commercial 3000 bp ladder (Kappa Biosystem/USA). 
University of Thi-Qar Journal Vol.10 No.3 SEP 2015

Web Site: https://jutq.utq.edu.iq/index.php/main Email: journal@jutq.utq.edu.iq

Table 1:Specific polymerase chain reaction primers and restriction enzymes for the Thr399Ile.

\begin{tabular}{|c|c|c|c|c|c|}
\hline Gene & \multicolumn{2}{|c|}{ SNP } & \multicolumn{1}{c|}{ Primer sequences } & product & Enzymes \\
\hline \hline \multirow{3}{*}{ TLR-4 } & \multirow{3}{*}{ Thr399Ile } & $F$ & 5-GGTTGCTGTTCTCAAAGTGATTTTGGGAGAA-3` & 406 & Hinf I \\
& & $R$ & 5-ACCTGAAGACTGGAGAGTGAGTTAAATGCT-3` & & \\
\hline
\end{tabular}

\section{Statistical analysis}

Data were analyzed using SPSS version 16 and Microsoft Office Excel 2007. Numeric variables were presented as mean $\pm \mathrm{SD}$ while nominal variables were expressed as number and percentage. student test was used to compare mean difference between any two groups in case of normal distribution. Odds Ratio, Chi-square and or corrected Ch-square tests were used for the study of associations between nominal variables. Spearman Rank Correlation coefficient was used to study correlations. P-value was considered significant when it was less than or equal to 0.05 .

\section{Results}

\section{Types of Bacterial isolates}

Patients with E. coli infection accounted for 26 (53.06\%); other culture results were as follows: 7 (14.29\%) K. pneumonia, 9 (18.37\%) P. aeruginusa, 4 (8.16\%) Proteus and 3 (6.12\%) K.oxytoca . All control subjects were free of infection. These results are shown in table 2. 
Table 2: Types of isolated bacteria in patients enrolled in the present study.

\begin{tabular}{|l|c|c|}
\hline \multicolumn{1}{|c|}{ Types of isolated bacteria } & No. & $\%$ \\
\hline E. coli & 26 & 53.06 \\
\hline K. pneumonea & 7 & 14.29 \\
\hline P.aeruginusa & 9 & 18.37 \\
\hline Proteus & 4 & 8.16 \\
\hline K.oxytoca & 3 & 6.12 \\
\hline Total & 49 & 100.00 \\
\hline
\end{tabular}

Distribution of patients and control subjects according to TLR4 C/T (Toll-like receptor-4 gene polymorphism)

The enzyme HinfI recognizes the sequence GANTC, and accordingly, it cuts PCR product of homozygous mutant genotype (TT) into two bands (377 and 29 bp), while heterozygous genotype (CT) is cut into three bands (406, 377, and 29 bp), whereas, homozygous wild genotype is not affected (the band size is 406 bp) (figure 1).

The results of the current study, show the presence of a correlation between the genotypes of the TLR4 gene and the incidence of development Urinary Tract Infection, as the results show the significant difference between patients and healthy controls when genotype Heterozygous (Thr / Ile) with $(\mathrm{OR}=1.577)$, while the genotype Homozygous (Ile / Ile) show no significant difference between the patients and control group with $(\mathrm{OR}=0.525)$ Table (3) . 
University of Thi-Qar Journal Vol.10 No.3 SEP 2015

Web Site: https://jutq.utq.edu.iq/index.php/main Email: journal@jutq.utq.edu.iq

Table 3: Distribution of patients and control subjects according to TLR4C/T (Toll-like receptor4 gene polymorphism).

\begin{tabular}{|l|l|l|l|c|c|l|}
\hline Genotype & Control & $\mathbf{\%}$ & Patients & \% & OR & 95\% CI \\
\hline Wild type & 25 & 100 & 48 & 97.9 & 1.0 & $\ldots \ldots \ldots \ldots$ \\
\hline Homozygous & 0 & 0 & 0 & 0 & 0.525 & $0.010-27.284$ \\
\hline Heterozygous & 0 & 0 & 1 & 2 & 1.577 & $0.062-40.129$ \\
\hline
\end{tabular}

OR: Odd Ratio

CI: Confidence Interval

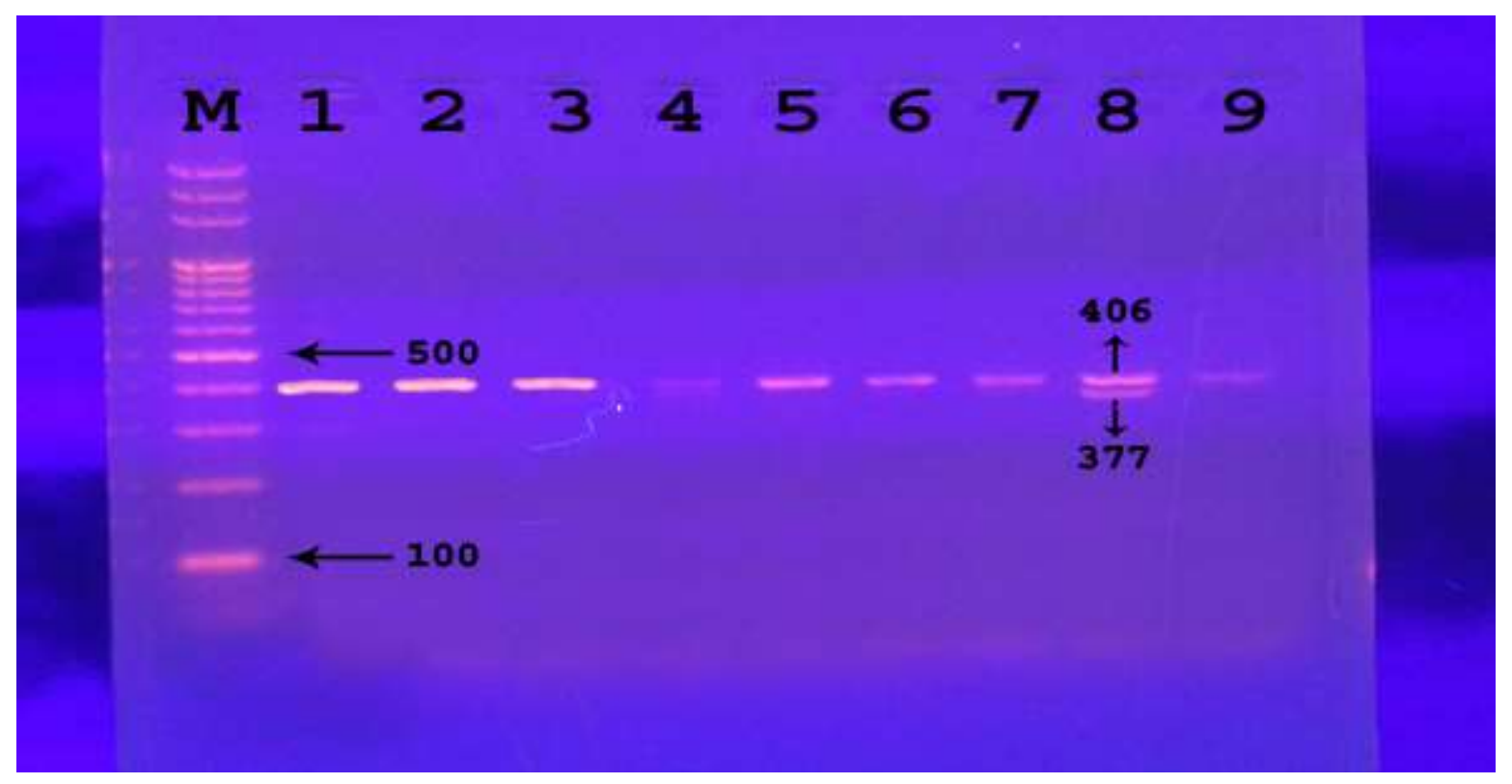

Figure 1 : Agarose gel electrophoresis for digested TLR-4 gene of UTI patients. Bands were fractionated by electrophoresis on a $3 \%$ agarose gel $(1 \mathrm{~h} ., 80 \mathrm{~V} / \mathrm{cm}, 1 \mathrm{X}$ Tris-acetic buffer) and visualized under U.V. light after staining with ethidium bromide staining.(M :100 - 3000bp ladder); using restriction enzyme HinfI . Lane: 1, 2,3,4,5,6,7,9 (Intact sample G Allele 406 bp fragment or wild type $\mathrm{C} / \mathrm{C}$ ); Lane:8); ( mutant sample $\mathrm{C} / \mathrm{T}$ or mutant heterozygous) . 


\section{Discussion}

\section{Bacterial isolates.}

Microorganisms isolated from (49) Gram -ve culture-proven bacteriuric are shown in table (2).E. coli form the majority of strains isolates $53.06 \%$ while pseudomonas aeruginusa; Klebsiella pneumonia; proteus sp.; Represents 18.37\% , 14.29\%, 8.16\% respectively .these finding are different from that of other works (Nicolle, 1993;AL- Dujailyet al.,2003).E coli is an important pathogen in urinary tract, particularly uropathogenic strains through possessing adhesion pili and other adhessins that predispose bacterial binding to the urothelium ( Jasmina et al. 2001, Soderhall, 2001). In addition to that E. coli possess many other tools make it potent pathogen to urinary tract and other sites of the body (Brooks et al., 2007). So for the above mentioned criteria $E$. coli took the first rank of isolation from urinary tract infection in this study.

\section{TLR4 C/T (Toll-like receptor-4 gene polymorphism)}

The results of statistical analyses for Toll-like receptor-4 gene polymorphism showed that only one patient $(2.04 \%)$ had Mutant heterozygous type $\mathrm{C} / \mathrm{T}$ while all other patients and control subjects showed Wild homozygous type $\mathrm{C} / \mathrm{C}$, as shown in table(3). These results indicate that there correlation between polymorphism of TLR-4 gene and Urinary Tract Infection .

This result is not in accordance with that obtained by of Al-Mayahet al. (2014) whom Found no significant association of Bladder Cancer with SNPs (Thr399Ile). Yoon. (2006), whom found no genetic polymorphisms were detected in Patients with Bacteremia of this study, suggesting that it is very rare in Korean.

Also Chaloob and Abdul-Mohsen,(2014). Found that The SNPs Thr399Ile may not be considered as a risk factor that increases susceptibility to $\mathrm{T}$. vaginalis infection. 


\section{University of Thi-Qar Journal Vol.10 No.3 SEP 2015}

Web Site: https://jutq.utq.edu.iq/index.php/main Email: journal@jutq.utq.edu.iq

And these findings were agree with the result of Zhu et al. (2013) found that the two SNPs Asp299Gly and Thr399Ile were significantly associated with increased risk of overall cancers.

Susceptibility to lethal infections throughout a person's lifetime may be significantly dependent on genetic factors such as genetic polymorphisms (Lin and Albertson, 2004; Angus etal., 2003). The role of a TLR4 polymorphism on the susceptibility to infections is still controversial and it is currently unresolved whether a hyporesponsive LPS signaling pathway is beneficial or detrimental to the host (Arbouret al., 2000; Agnese et al., 2002; Morreet al., 2003).

TLR-4 gene polymorphism may associated with susceptibility UTIs, but this relationship could vary in different populations and disease types. Further surveys of more cases and different races are needed to make conclusive statements (Yin et al., 2010).

A separate study found that both D299G and T399I wereassociated with systemic inflammatory hyporesponsivenesafter LPS inhalation (Michel et al., 2003). It has been reported that genetic polymorphisms vary according to race and certain other factors (Nakadaet al., 2005; Yoon et al.,2006;), In particular, Asian people seem to have a very rare TLR-4 mutation Thr(399)Ile polymorphisms (Nakada.2005; Yoon et al., 2006; Hang et al.,2004).

\section{References}

Agnese D.; Calvano J.; Hahm S.; Coyle S.; Corbett S.; Calvano S.; Lowry S. (2002). Human Toll-like receptor 4 mutations but not CD14 polymorphisms are associated with an increased risk of gram-negative infections. Journal Infection Disease 186: 1522-5.

AL- Dujaily A.; Mohammad A.; Hammodi A. (2003). UTI. during pregnancy in Tikrit. KufaMedical J., Accepted .

Al-Mayah Q.; Al-Dabagh M.; Ali A. (2014). Toll-Like Receptor 4 Gene Polymorphisms and Bladder Cancer. Med JBab. 11(2):409-413

Andersen-Nissen E., Hawn T., Smith et al K. (2007). "Cutting edge: Tlr5-/- mice are more susceptible to Escherichia coli urinary tract infection," J Immunol. 178 (8): 4717-4720.

Angus D.; Burgner D.; Wunderink R.; Mira J.; (2003). Gerlach H, Wiedermann CJ, Vincent JL. The PIRO concept: P is for predisposition. Crit Care. 7: 248-51. 
Web Site: https://jutq.utq.edu.iq/index.php/main Email: journal@jutq.utq.edu.iq

Arbour N.; Lorenz E.; Schutte B.; Zabner J; Kline J.; Jones M.; Frees K.; Watt J.; Schwartz D. (2000). TLR4 mutations are associated with endotoxin hyporesponsiveness in humans. Nat. Genet. 25: 187-91.

Bien J.; Sokolova O. and Bozko P. (2012). Role of Uropathogenic Escherichia coli Virulence Factors in Development of Urinary Tract Infection and Kidney Damage. Internatio. J. Nephrol. 15 pages.

Chaloob F. and Abdul-Mohsen A. (2014). Association of Toll-Like Receptor 4 Gene polymorphism with Trichomonasvaginalis Infection in Iraqi Women. Med.J. B. 11(1).

Darouiche R.; Donovan W.; Del Terzo M.; Thornby J.; Rudy D. and Hull R. (2001). "Pilot trial of bacterial interference for preventing urinary tract infection," Urolo. 58 (30): 339344.

Foxman B. (2003). "Epidemiology of urinary tract infections: incidence,morbidity, and economic costs," Disease-a-Month. 49 (2): 53-70.

Hang J.; Zhou W.; Zhang H.; Sun B.; Dai H.; Su L.; Christiani D. (2004). TLR4 Asp299Gly and Thr399Ile polymorphisms are very rare in the Chinese population. J Endotoxin Res 10:238-240.

Hedlund M.; Frend'eus B.; Wachtler C.; Hang L.; Fischer H. and Svanborg C. (2001). "Type 1 fimbriae deliver an LPS- and TLR4-dependent activation signal to CD14negative cells," Mol. Mic. 39 (3): 542-552.

Hooton T. and Stamm W. (1997). "Diagnosis and treatment of uncomplicated urinary tract infection," Inf. Dis.Clin.N. A.11(3): 551-581.

Hull R.; Rudy D.; Donovan W. et al. (2000). "Urinary tract infection prophylaxis using Escherichia coli 83972 in spinal cord injured patients," J.Uro. 163(3): 872-877.

Iwasaki, A. and Medzhitov, R. (2004). Toll-like receptor control of the adaptive immune response. Nat. Immunol. 5:987-995. 
Web Site: https://jutq.utq.edu.iq/index.php/main Email: journal@jutq.utq.edu.iq

Iwasaki, A. and Medzhitov, R. (2010). Regulation of adaptive immunity by the innate immune system. Sci.327: 291-295.

Jasmina, V.; Slavko S. and Blazenka I. (2001). Low virulence of E. coli strains causing exacerbation of chronic pyelonephritis Acta. Clinic. Croat. 40:165-170.

KövesB., (2014). The role of bacterial virulence factors in the clinical course of urinary tract infections . Ph.D. Thesis. Department of Microbiology, Immunology and Glycobiology, Institute of Laboratory Medicine, Lund University.

Lin M. and AlbertsonT. (2004). Genomic polymorphisms in sepsis. Crit. Care. Med. 32: 56979 .

Michel, O., LeVan, T., Stern, D. et al. (2003). Systemic responsiveness to lipopolysaccharide and polymorphisms in the toll-like receptor 4 gene in human beings. J. Allergy Clin. Immunol. 112: 923-929.

MorreS., Murillo L., Bruggeman C., Pena A. (2003). The role that the functional Asp299Gly polymorphism in the Toll-like receptor 4 gene plays in susceptibility to Chlamydia trachomatis-associated tubal infertility. J. Infect. Dis. 187: 341-2.

NakadaT., Hirasawa H., Oda S., Shiga H., Matsuda K., Nakamura M., Watanabe E., Abe R., Hatano M., Tokuhisa T. ( 2005). Influence of Toll-like receptor 4, CD14, tumor necrosis factor, and interleukine-10 gene polymorphisms on clinical outcome in Japanese critically ill patients. J. Surg. Res. 129:322-328.

NicolleL. (1993). UTIs in long -term care facilities. Inf. Cont. Hos.Epidemiol. 14: 220- 5.

ReismannP.(2009).Study of the Toll-like receptor 4 gene polymorphisms in diseases presenting with subclinical and chronic inflammation(diabetes mellitus, ischemic stroke, periodontitis) Ph.D. thesis. Semmelweis University.Pp3.

SadlerI., Chiang A., Kurihara T., Rothblatt J., Way J. and Silver P. (1989). "A yeast gene important for protein assembly into the endoplasmic reticulum and the nucleus has homology to DnaJ, an Escherichia coli heat shock protein," j. C.Biol. 109 (6I): 26652675.

SamuelssonP., Hang L., Wullt B., Irjala H. and Svanborg C. ( 2004). "Toll-like receptor 4 expression and cytokine responses in the human urinary tract mucosa," Inf. Immun.72(6): 3179-3186. 
Web Site: https://jutq.utq.edu.iq/index.php/main Email: journal@jutq.utq.edu.iq

Schroder, N. and Schumann, R. (2005). Single nucleotide polymorphisms of toll-like receptors and susceptibility to infectious diseases. Lancet Infect. Dis. 5:156-164.

Soderhall, M. (2001). The importance of E. coli fimbriae in UTI, Karolinska University Press. Stockholm, Sweden.

SongJ. and Abraham S., (2008). "Innate and adaptive immune responses in the urinary tract," Europ. J. Clinic.Inves. 38 (2): 21-28.

SvanborgC. and GodalyG. (1997). "Bacterial virulence in urinary tract infection," Inf. Dis.Cli.N.America. 11 (3):513-529.

TrautnerB., Hull R. and Darouiche R. (2003). "Escherichia coli 83972 inhibits catheter adherence by a broad spectrumofuropathogens," Urology. 61 (5): 1059-1062.

Vandepitte J, Verhaegen J, Engbaek K. (2003). Basic laboratory procedures in clinical bacteriology. ${ }^{2} \mathrm{nd}$ ed. World health organization, Geneva: 110.

Yin X., Hou T., Liu Y., Chen J., Yao Z. et al. (2010). Association of Toll-Like Receptor 4 Gene Polymorphism and Expression with Urinary Tract Infection Types in Adults. PLOSONE. 5(12).

YoonH., Choi J., Kim C., Park Y., Kim M., Kim Y., Shin S., Kim J., Song Y. (2006). Lack of Toll-like receptor 4 and 2 polymorphisms in Korean patients with bacteremia. $J$. Korean Med.Sci. 21:979-982.

Zhu, L.; Yuan, H.; Jiang, T.; Wang, R.; Ma, H. and Zhang, S. (2013). Association of TLR2 and TLR4 polymorphisms with risk of cancer: a meta-analysis. PLoS ONE, 8:82858. 